\title{
Jaguar Panthera onca predation of marine turtles: conflict between flagship species in Tortuguero, Costa Rica
}

\author{
D. Verísimo, D. A. Jones, R. Chaverri and S. R. Meyer
}

\begin{abstract}
Predation can be an important driver of population dynamics but can also pose a dilemma to conservation managers if the species interacting are of conservation concern or have a high public profile. For 5 years we conducted regular transect surveys to monitor the spatial and temporal patterns of predation of adult marine turtles by jaguars Panthera onca in Tortuguero National Park, Costa Rica. Predation occurs throughout the study site on Tortuguero Beach although at lower rates at the northern and southern ends, probably because of increased human presence in these areas. There was a marked increase in predation, from an average of $<2$ turtles predated per survey in the first season to $>5$ predated per survey in the last, with 676 jaguar-predated marine turtles recorded during the study period. With a minimum of 189 individuals predated in the last season, predation of adult turtles has now reached a magnitude never before recorded in a marine turtle rookery. Although the nesting population of marine turtles in Tortuguero is one of the largest in the world and suffers from both direct and indirect anthropogenic pressures, the increase in predation by jaguars makes this ecological interaction relevant to the management of both the jaguar and marine turtle populations. The situation could lead to a potential conflict in conservation strategies that, given the flagship role of the species involved, will need to be addressed both in the context of species management and conservation marketing.
\end{abstract}

Keywords Caribbean, Chelonia mydas, Dermochelys coriacea, diet, green turtle, jaguar, leatherback turtle, marine turtle, Panthera onca

\section{Introduction}

A $\mathrm{s}$ biodiversity faces growing anthropogenic pressures conservationists increasingly face conflicts between the management of different species. The resolution of such conflicts often requires making difficult decisions,

D. VERÍSSIMO* (Corresponding author), D.A. JONEs, R. CHAVERRI and S.R. MEYER Global Vision International Costa Rica, 3rd floor, The Senate, Exeter, EX1 1UG, UK.E-mail dv38@kent.ac.uk

${ }^{*}$ Also at: Durrell Institute of Conservation and Ecology, University of Kent, Canterbury, UK

Received 23 April 2011. Revision requested 8 June 2011.

Accepted 24 August 2011. First published online 16 April 2012. particularly when the species are of conservation concern and/or have a high media profile (Simberloff, 1998). This is especially true when it comes to predatory interactions (Coonan et al., 2005; Gibson, 2006; Pudyatmoko et al., 2007) that, while involving the death of individuals, are critical in the dynamics of ecosystems (Heithaus et al., 2008).

Marine turtles and jaguars Panthera onca are widely recognized as conservation flagship species (Caro et al., 2004; Eckert \& Hemphill, 2005) and large-scale projects such as Operation Green Turtle (Bjorndal et al., 1999) and Paseo Pantera (Ceballos et al., 2002) have been developed to conserve them. All marine turtle species occurring around the American continent are threatened with extinction, with the green turtle Chelonia mydas categorized as Endangered and leatherback Dermochelys coriacea and hawksbill Eretmochelys imbricata turtles categorized as Critically Endangered (IUCN, 2011; but see Broderick et al., 2006; Godfrey \& Godley, 2008; Seminoff \& Shanker, 2008). Although heavily affected by a range of natural predators during their early life stages (Fowler, 1979; Opay, 1998; Engeman et al., 2005) adult marine turtles have only a small number of documented regular predators (see Heithaus et al., 2008, for a review). Together with a lack of available data this has contributed to the assumption that predation has little impact on adult turtles (Heithaus et al., 2008).

Tortuguero National Park in Costa Rica is a globally important area, hosting one of the largest green turtle rookeries (Bjorndal et al., 1999), together with nesting populations of leatherback and hawksbill turtles (Troëng et al., 2004, 2005). The Park also contains an unknown number of jaguars. Although categorized globally as Near Threatened (Caso et al., 2008) jaguar populations in Costa Rica are considered to be highly threatened (Sanderson et al., 2002; Salom-Pérez et al., 2007). Despite the absence of a current estimate of the population Tortuguero National Park and the adjoining Barra del Colorado Wildlife Refuge were identified in an expert consultation as a priority Jaguar Conservation Unit, considered critical for the long-term survival of the species (Zeller, 2007).

Information on jaguar predation of marine turtles is sparse and anecdotal, with published records from Suriname (Autar, 1994) and Costa Rica (Carrillo et al., 1994; Chinchilla, 1997; Troëng, 2000; Salom-Pérez, 2005). Nevertheless, this ecological interaction is also reported to occur in French Guiana (J. Chevalier, pers. comm., in Troëng, 2000) and Guyana (R. de Freitas, pers. comm.). In 
Tortuguero National Park jaguar predation of marine turtles has been monitored to varying degrees for over a decade. Regular turtle track surveys on Tortuguero Beach began in 1971 (Bjorndal et al., 1999; Troëng \& Rankin, 2005) but prior to 1997 there were only two records of green turtles being killed by jaguars, in 1981 (Carrillo et al., 1994) and 1984 (J. Mortimer, pers. comm., in Troëng, 2000). In 1997 the Caribbean Conservation Corporation (now Sea Turtle Conservancy) recorded four marine turtle mortalities as jaguar kills (Troëng, 1997). The following nesting season a minimum of 25 green turtle deaths were attributed to jaguars (Troëng, 1999).

In 2002 the Costa Rican Ministry of the Environment and Energy (now Ministry of the Environment, Energy and Telecommunications) began a study in Tortuguero National Park, focusing solely on jaguar predation of nesting marine turtles, which aimed to record not only the total number of marine turtles killed by jaguars but also, using track surveys, how jaguar and marine turtles use the beach habitat. After 2003 the study ceased because of a lack of resources. In July 2005 the Ministry invited Global Vision International Costa Rica to establish a systematic monitoring programme in the Park based on the discontinued investigations.

In this study we aimed to document the temporal and spatial trends of jaguar predation of marine turtles in Tortuguero National Park and highlight potential implications for the conservation of the species concerned and the need for similar studies in other locations where their ranges overlap. We also discuss what challenges a conflict between two high profile taxa may bring to the use of such species in campaigns for fundraising and for influencing people's behaviour.

\section{Study area}

The 72,359 ha Tortuguero National Park, which includes areas of both land and sea, lies along the north Caribbean coast of Costa Rica (Bermúdez \& Hernández, 2004). It is managed by Área de Conservación Tortuguero under the Ministry of the Environment, Energy and Telecommunications. The rookery at Tortuguero Beach is on a c. $30 \mathrm{~km}$ stretch of coast from the Tortuguero River mouth in the north to the Jalova River mouth in the south. Bordering a total of c. $6.2 \mathrm{~km}$ of the beach in the north are several tourist lodges, a small airport for light aircraft and Tortuguero village, the largest human settlement neighbouring the National Park. This study focuses on the National Park coastline, which begins at the southern end of the village and continues for c. $23.8 \mathrm{~km}$ to the river mouth at Jalova (Fig. 1). The study area was divided into $805-\mathrm{m}$ (halfmile) sections, numbered 1-29 from north to south, along a length of $23.3 \mathrm{~km}$ (14.5 miles), which corresponds to the area with historically high numbers of nesting marine turtles.
The beach within Tortuguero National Park is bordered by rainforest, with the exception of a small cattle ranch and coconut farm at the southern end.

\section{Methods}

Data collection took place over 176 surveys from July 2005 to June 2010. Surveys were conducted on foot at c. 3-4 $\mathrm{km} \mathrm{h}^{-1}$ along the length of the study area, once per week during each of the quarterly 9 -week research periods per year. Field teams of 4-6 researchers started at dawn, covering the width of the beach from the tide line to the vegetation to maximize detection. The teams recorded presence/absence of jaguars (i.e. tracks or scats) and marine turtle tracks for each $805-\mathrm{m}$ section of the study area. In both cases only fresh tracks that retained sufficient definition to be measured, and therefore could be identified accurately, were counted.

Upon detecting a turtle carcass teams would crossreference against previously recorded data (description, coordinates, location, estimated time since death) to avoid double-counting. If the team concluded the carcass had not been previously recorded it was examined for characteristic signs of a jaguar kill, such as bite marks to the neck or drag marks (Aranda Sánchez, 1981). In instances of marine turtle mortality in which insufficient remains were encountered to record the relevant data or the evidence indicated that jaguars were not involved (e.g. cut marks indicating poaching by humans), information was recorded but excluded from analysis. The only terrestrial species present locally that are known to predate adult marine turtles are jaguars, humans and the American crocodile Crocodylus acutus, which has a distinctive attack pattern (Ortiz et al., 1997) and for which there are no local records of predation. Consequently kills were recorded as jaguar predation when the evidence was compatible with jaguar predation and there were no signs of predation by other species.

For each marine turtle carcass determined to be the result of jaguar predation teams recorded evidence of predation (photographs, descriptive notes, estimated time since death), curved carapace length, location, study area section, vertical position on the beach, location photograph, and flipper tag numbers (where present) for each individual turtle. Data on presence/absence of turtles and jaguars were coded as binary variables. Data on predation events were coded using the number of individuals killed.

We investigated temporal patterns both among and within years. To account for differential survey effort we averaged the results across the number of surveys conducted during the relevant period. As the study began at the start of the green turtle nesting season in 2005 (July), the analysis of the data was considered on an annual basis from 1 July to 30 June, to capture each full year of data.

As we were dealing with count data and small sample sizes a Poisson generalized linear model was used to 


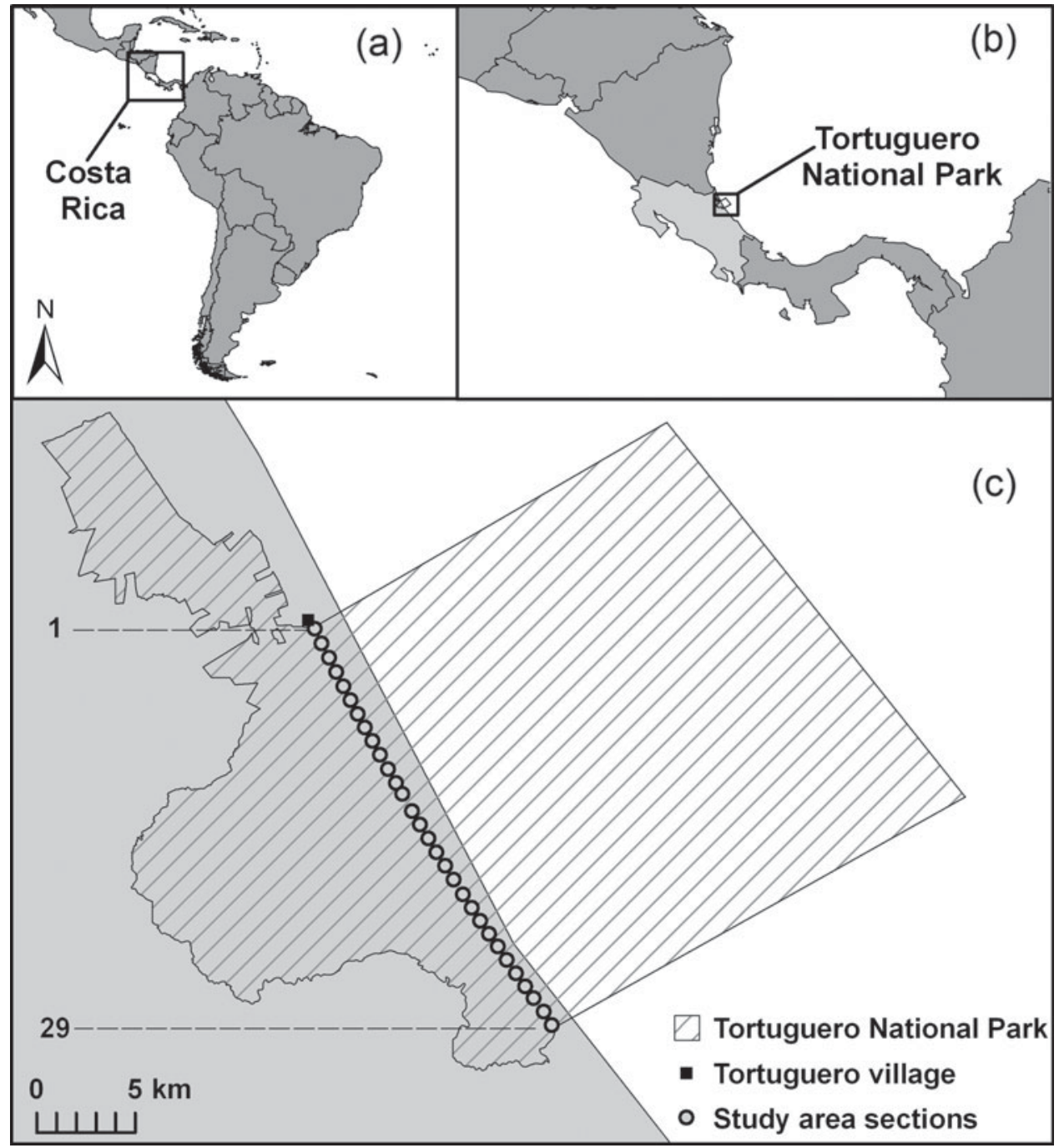

FIg. 1 (a) Costa Rica, (b) the location of Tortuguero National Park on the north Caribbean coast, and (c) the 30 numbered study sections (see text for details) on Tortuguero Beach. investigate the spatial and temporal relationships between predation, presence of turtles, presence of jaguars and, for spatial scale only, distance to human settlements. To investigate the temporal trends in jaguar predation of marine turtles, using presence and predation data, we used linear regression. All statistical tests were performed using SPSS v. 18.o (SPSS, Chicago, USA).

\section{Results}

The mean number of surveys per month was three, with 5 months having a single survey and 1 month having seven surveys. There were no surveys in January 2006, October 2008 and September 2009 because of logistical constraints or adverse weather. A total of 676 turtles were recorded as killed by jaguars. All were green turtles except for three hawsbill turtles and one leatherback turtle. The majority of the turtles were found lying on their plastron. As documented by Troëng (2000) individuals seemed to be killed by a bite to the neck, with only the neck muscles (and occasionally the area around one of the flippers) eaten (Plate 1).

Within years turtle presence peaked during the nesting seasons, as expected (Fig. 2a). Jaguar presence, determined from prints and scats, was recorded throughout the year, with the lowest detected presence between July and October, unexpectedly coinciding with the highest recorded presence of turtle tracks (Fig. 2a). As expected, analysis of mean monthly trends for predation, jaguar presence and turtle presence during the entire study period shows that the seasonal presence of turtles is the main determinant of predation $\left(\chi_{1}^{2}=77.95, \mathrm{P}<0.001, \mathrm{df}=1\right)$ whereas jaguar presence was not as important $\left(\chi_{1}^{2}=0.25, \mathrm{P}=0.620\right.$, $\mathrm{df}=1)$.

Analysis of temporal trends among years revealed a relatively constant jaguar and turtle presence for the last 4 years of the 5-year study period (Fig. 2C). Predation showed a positive linear increase $\left(R^{2}=0.90, F=27.092, \mathrm{P}=0.014\right.$, $\mathrm{df}=4$ ), with the mean number of turtles found predated per survey increasing from $<_{2}$ in 2005/2006, to $>_{5}$ in 

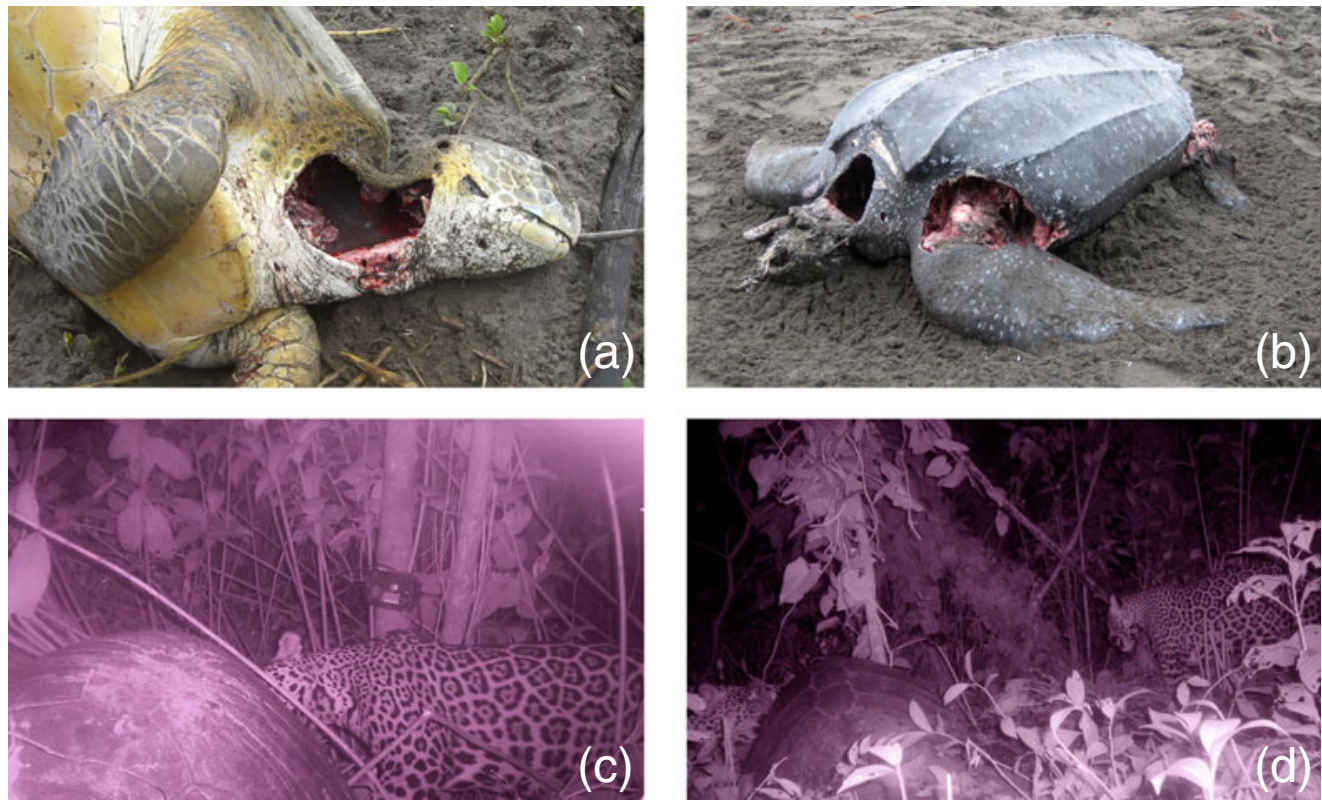

Plate 1 (a) Green turtle Chelonia mydas and (b) leatherback turtle Dermochelys coriacea, with typical signs of jaguar Panthera onca predation, and (c, d) camera-trap photographs of jaguars feeding off green turtles. (All photographs GVI Costa Rica).
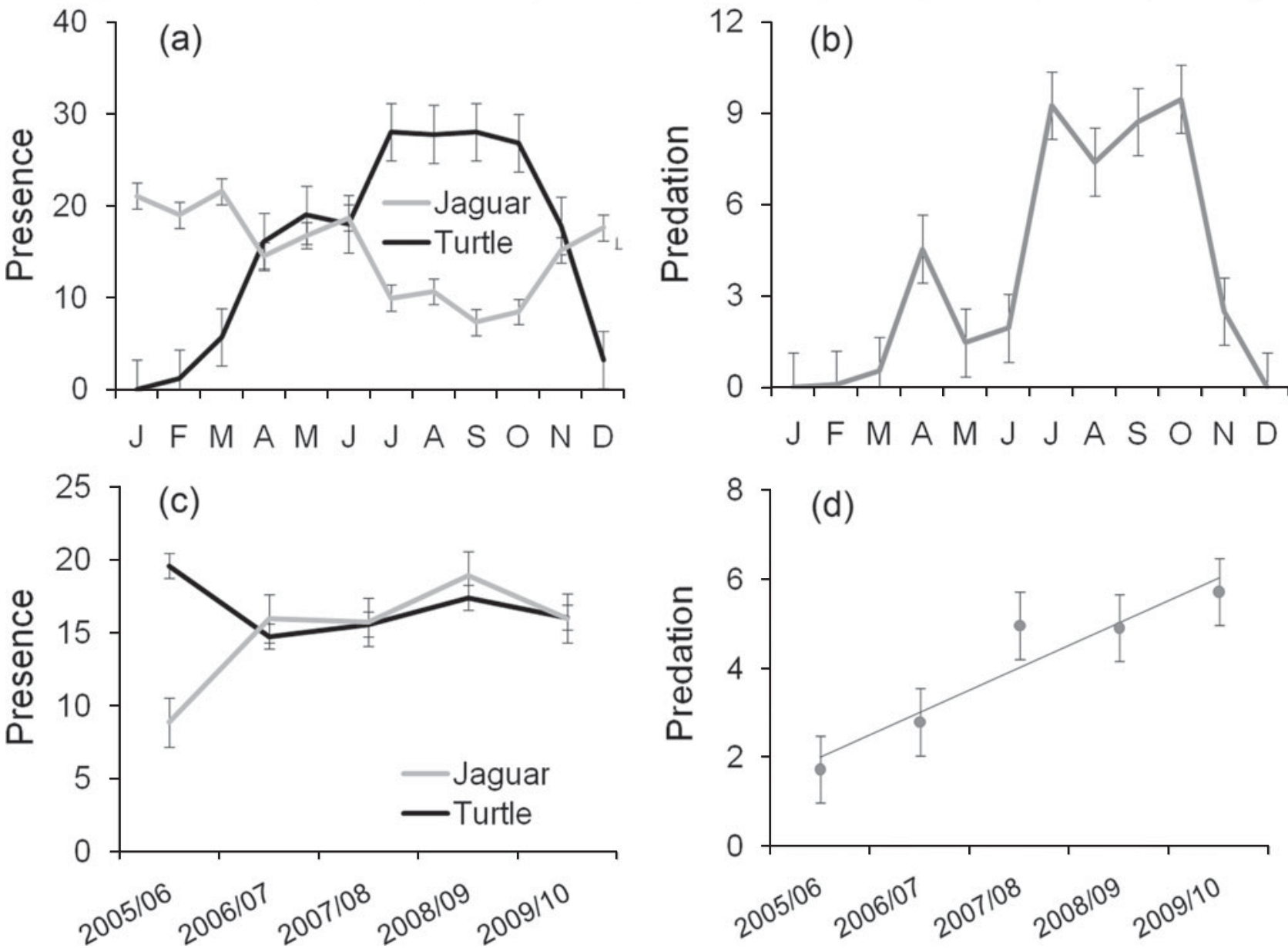

FIg. 2 (a) Mean number \pm SE of $805-\mathrm{m}$ (half-mile) sections of Tortuguero Beach (Fig. 1) with signs of jaguar Panthera onca and marine turtle presence per month, (b) mean number \pm SE of turtles found killed by jaguars per month, from 1 July 2005 to 30 June 2010 , (c) mean number \pm SE of 805-m sections with signs of jaguar and turtle presence per year, and (d) mean number \pm SE of turtles killed by jaguars per year. In (c) and (d) the 12 months are from 1 July to 30 June. 

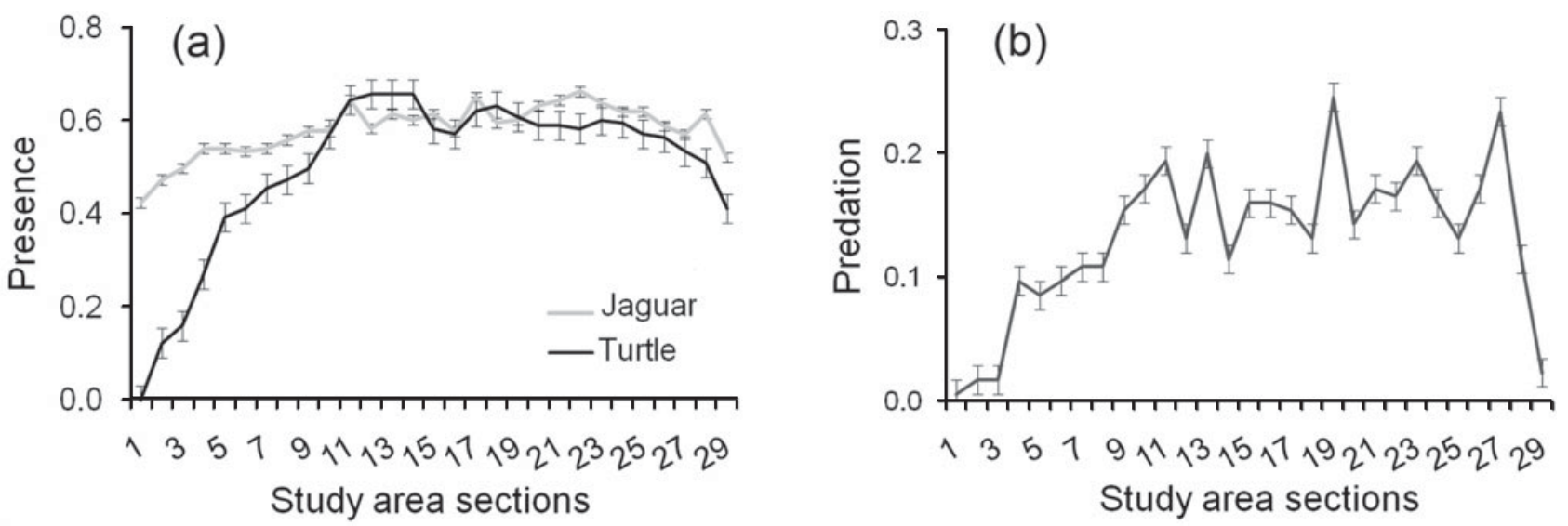

FIg. 3 (a) Mean number \pm SE of signs of jaguar and turtle presence, and (b) mean number \pm SE of turtles killed by jaguars, per $805-m$ (half-mile) section of Tortuguero Beach (Fig. 1), from 1 July 2005 to 30 June 2010.

2009/2010 (Fig. 2d) and with a total of 189 jaguar-predated turtles recorded in the final season.

Jaguars and marine turtles were detected throughout the study area, although detection of presence of both jaguars and turtles declined at the extreme north and south of the study area (Fig. 3a). Predation followed the same pattern (Fig. 3b). Both jaguar presence $\left(\chi_{1}^{2}=36.90, \mathrm{P}<0.001\right.$, $\mathrm{df}=1)$ and increased distance to human settlements $\left(\chi_{1}^{2}=7.84, \mathrm{P}=0.005, \mathrm{df}=1\right)$ were important predictors of predation by jaguars, with turtle presence less relevant $\left(\chi_{1}^{2}=0.64, \mathrm{P}=0.425, \mathrm{df}=1\right)$. Predated turtles were not evenly distributed across the width of the beach $\left(\chi_{1}^{2}=9.36\right.$, $\mathrm{P}<0.001, \mathrm{df}=2$ ), with a higher proportion found in the open sand area (44\%) and vegetation $(37 \%)$ as opposed to the zone between them (14\%).

\section{Discussion}

In marine turtle biology Tortuguero Beach is one of the most intensively studied beaches, with monitoring for marine turtle nesting activity having started in the early 1970s (Bjorndal et al., 1999). This is also the case for the study of jaguar predation of marine turtles, with incidental records dating back to the 1980 s and regular reporting beginning in 1997. However, because of substantial differences in methodology, study period and annual effort or nesting season, it was not previously possible to examine trends in predation by jaguars on this beach.

\section{The importance of marine turtles as a prey item}

The jaguar's diet has been extensively studied and the species is an opportunistic predator of a wide variety of prey species (Chinchilla, 1997; Taber et al., 1997; Garla et al., 2001; Polisar et al., 2003). Nonetheless, the level of predation in Tortuguero National Park suggests a previously undocumented relationship between marine turtles and jaguars. Evidence indicates that jaguars are present throughout the year. With few or no marine turtles recorded for 3 months of each year (Fig. 2a) and comparatively little predation occurring outside the green turtle nesting season (Fig. 2b), this may indicate that the coastal habitat is of importance to jaguars in this region for reasons additional to hunting. Predation of marine turtles may therefore be opportunistic in those months when the species' ranges overlap. However, there was a decrease in jaguar presence when marine turtle presence was highest (Fig. 2a). This could be explained by retraction of the jaguar's range because of an increase in the availability of other prey types. However, we believe these results to be an artefact of the low detectability of jaguar prints during the height of the green turtle nesting season. The very high density of turtle tracks are likely to erase and obscure the predator's signs. This interpretation is supported by the data for September and October, when jaguar-predated marine turtles were recorded over a wider area than other signs of jaguar presence.

Although the number of jaguars preying on marine turtles is unknown and there are no studies of the composition of the diet of jaguars at Tortuguero National Park, the increasing predation of marine turtles suggests that their importance as prey is increasing. Predation was less at the northern and southern ends of the beach (Fig. 3a), where human disturbance is higher. Any further disturbance or encroachment could not only diminish the available jaguar habitat but could also limit jaguar access to an important prey item. To establish the ecological significance of this interaction it would be valuable to estimate the size of the jaguar population of Tortuguero National Park and the proportion of their diet made up by marine turtles (Salom-Pérez, 2005).

\section{Predation by jaguars as a potential threat to marine turtles}

Adult mortality of long-lived, large-bodied animals such as marine turtles can have profound ecological impacts 
(Heithaus et al., 2008), especially in populations simultaneously affected by anthropogenic factors. The impact of jaguar predation has nevertheless been previously overlooked on Tortuguero Beach because of the large number of marine turtles that nest there (Troëng, 2000; de Haro \& Troëng, 2005; de Haro \& Harrison, 2006) and the large numbers of adult marine turtles harvested from the population by people, particularly in the Nicaraguan feeding grounds (Campbell \& Lagueux, 2005). Whilst the current predation levels do not appear to be the most immediate threat to the Tortuguero rookery, it is not possible to dismiss the potential impact as insignificant given the total number of adult turtles predated and the annual increase since our study began (Fig. 2d). However, presence/absence data may be too coarse to examine how predation is affected by changes in annual abundance of nesting marine turtles. Nonetheless, given the wide non-linear variation in the estimated numbers of turtles nesting during the study period (Atkinson et al., 2009, 2010) we are confident that the increase in predation is unrelated to the availability of nesting turtles. Jaguar predation should therefore rank alongside, if not higher than, other documented threats. For example, feral domestic dogs predated 119 nests in the study area in 2007 (Nolasco et al., 2007) and have been the target of conservation measures locally since 1977 (Fowler, 1979; Atkinson et al., 2009). Given the low hatching rate and hatchling survivorship of green turtles in Tortuguero (Fowler, 1979; Bjorndal, 1980) nest predation is likely to have fewer implications for the management of the rookery than the increasing numbers of adult female turtles lost to jaguars.

Jaguars are known to predate four species of marine turtle (Autar, 1994): green, leatherback, hawksbill and olive ridley Lepidochelys olivacea, all of which are globally threatened (IUCN, 2011). To examine how widespread this ecological interaction is further studies need to be undertaken where the range of the jaguar overlaps with that of these species.

\section{When flagship species clash}

Conservation campaigns for behaviour change and to raise funds have long relied on flagship species to engage their target stakeholders (Smith et al., 2011; Veríssimo et al., 2011). This approach has limitations when one high profile taxon, such as the jaguar, becomes a potential threat to other high profile taxa, such as marine turtles (Simberloff, 1998). In such a case it is important to manage not only the ecological and behavioural interactions between these species but also the relationships between stakeholders such as local communities, conservation organizations and foreign donors. Management strategies need to take into account the human context and be effectively communicated to all relevant stakeholders. This would not only avoid conflicts between those working to conserve different taxa but also avoid conflicts between local stakeholders and those using jaguars and sea turtles as flagship species for conservation. Such conflicts have already occurred in some places where marine turtle densities have increased markedly (Balazs et al., 1993; Lal et al., 2010). Conservationists need therefore to be aware of the potential trade-offs involved in the use of flagship species to market biodiversity conservation (Smith et al., 2011; Veríssimo et al., 2011) and to recognize the importance of establishing relationships with their target stakeholders through, for example, the use of social marketing principles (Veríssimo et al., 2011).

\section{Conclusions}

The responsible authorities in Costa Rica may soon be faced with a management dilemma. On the one hand the predation of Endangered and Critically Endangered species of marine turtles by jaguars is increasing and it is unclear as to the level at which it will stabilize. On the other hand the degree to which marine turtles are of importance in the diet of the Near Threatened jaguar in and around Tortuguero National Park is unknown. Improved understanding of these issues will be required for appropriate management of the marine turtles and the jaguar. It has been hypothesized that the increase in turtle predation is driven by destruction and fragmentation of the jaguar's habitat (Troëng, 2000) as a result of human activities around the National Park and in its buffer zone. Management of this predator-prey relationship may therefore need to take into consideration not only the terrestrial and marine components of the Park but also areas beyond its borders.

\section{Acknowledgements}

We thank all Global Vision International Costa Rica research staff and volunteers involved in collecting the data presented, and the Costa Rican Ministry of Environment, Energy and Telecommunications for its long-term support of this project. We also thank $\mathrm{Dr}$ Matthew Linkie for his insightful comments.

\section{References}

Aranda Sánchez, J.M. (1981) Rastros de los Mamíferos Silvestres de México. Instituto nacional de investigaciones sobre recursos bioticos, Xalapa, Mexico.

Atkinson, C., Nolasco, D. \& Harrison, E. (2010) Report on the 2010 Leatherback Program at Tortuguero, Costa Rica. Caribbean Conservation Corporation, San Pedro, Costa Rica.

Atkinson, C., Ramos, L.B. \& Harrison, E. (2009) Report on the 2009 Green Program at Tortuguero, Costa Rica. Caribbean Conservation Corporation, San Pedro, Costa Rica. 
Autar, L. (1994) Sea turtles attacked and killed by jaguars in Suriname. Marine Turtle Newsletter, 67, 11-12.

Balazs, G.H., Fujioka, R. \& Fujioka, C. (1993) Marine turtle faeces on Hawaiian beaches. Marine Pollution Bulletin, 26, 392-394.

Bermúdez, F. \& Hernández, C. (2004) Plan de Manejo del Parque Nacional Tortuguero. Área de Conservación Tortuguero, San Jose, Costa Rica.

BJorndal, K. (1980) Demography of the breeding population of the green turtle, Chelonia mydas, at Tortuguero, Costa Rica. Copeia, 1980, 525-530.

Bjorndal, K.A., Wetherall, J.A., Bolten, A.B. \& Mortimer, J.A. (1999) Twenty-six years of green turtle nesting at Tortuguero, Costa Rica: an encouraging trend. Conservation Biology, 13, 126-134.

Broderick, A.C., Frauenstein, R., Glen, F., Hays, G.C., Jackson, A.L., Pelembe, T. et al. (2006) Are green turtles globally endangered? Global Ecology and Biogeography, 15, 21-26.

Campbell, C.L. \& Lagueux, C.J. (2005) Survival probability estimates for large juvenile and adult green turtles (Chelonia mydas) exposed to an artisanal marine turtle fishery in the Western Caribbean. Herpetologica, 61, 91-103.

Caro, T., Engilis, Jr, A., Fitzherbert, E. \& Gardner, T. (2004) Preliminary assessment of the flagship species concept at a small scale. Animal Conservation, 7, 63-70.

Carrillo, E., Morera, R.A. \& Wong, G. (1994) Depredación de tortuga lora (Lepidochelys olivacea) y de tortuga verde (Chelonia mydas) por el jaguar (Panthera onca). Vida Silvestre Neotropical, 3 , 48-49.

Caso, A., Lopez-Gonzalez, C., Payan, E., Eizirik, E., Df Oliveira, T., Leite-Pitman, R. et al. (2008) Panthera onca. In IUCN Red List of Threatened Species v. 2011.2. Http://www. iucnredlist.org [accessed 2 February 2012].

Ceballos, G., Chávez, C., Rivera, A., Manterola, C. \& Wall, B (2002) Tamano poblacional y conservación del jaguar en la reserva de la biosfera Calakmul, Campeche, México. Fondo de cultura económica, UNAM, Mexico DF, México.

Chinchilla, F.A. (1997) La dieta del jaguar (Panthera onca), el puma (Felis concolor) y el manigordo (Felis pardalis) en el Parque Nacional Corcovado, Costa Rica. Revista de Biologia Tropical, 45, 1223-1229.

Coonan, T.J., Schwemm, C.A., Roemer, G.W., Garcelon, D.K. \& Munson, L. (2005) Decline of an island fox subspecies to near extinction. Southwestern Naturalist, 50, 32-41.

De Haro, A. \& Harrison, E. (2006) Report del Programa de Tortuga Verde 2007. Caribbean Conservation Corporation, San Pedro, Costa Rica.

De Haro, A. \& Troëng, S. (2005) Report on the 2005 Green Turtle Program at Tortuguero, Costa Rica. Caribbean Conservation Corporation, San Pedro, Costa Rica.

Eckert, K.L. \& Hemphill, A.H. (2005) Sea turtles as flagships for protection of the wider Caribbean region. Maritime Studies, 3, 119143.

Engeman, R.M., Martin, R.E., Smith, H.T., Woolard, J., Crady, C.K., Shwiff, S.A. et al. (2005) Dramatic reduction in predation on marine turtle nests through improved predator monitoring and management. Oryx, 39, 318-326.

FOWLER, L. (1979) Hatching success and nest predation in the green sea turtle, Chelonia mydas, at Tortuguero, Costa Rica. Ecology, 6o, 946-955.

Garla, R., Setz, E. \& Gobbi, N. (2001) Jaguar (Panthera onca) food habits in Atlantic rainforest of southeastern Brazil. Biotropica, 33, 691-696.

Gibson, L. (2006) The role of lethal control in managing the effects of apparent competition on endangered prey species. Wildlife Society Bulletin, 34, 1220-1224.
Godfrey, M.H. \& Godley, B.J. (2008) Seeing past the red: flawed IUCN global listings for sea turtles. Endangered Species Research, 6, 155-159. Heithaus, M.R., Wirsing, A.J., Thomson, J.A. \& Burkholder, D. A. (2008) A review of lethal and non-lethal effects of predators on adult marine turtles. Journal of Experimental Marine Biology and Ecology, 356, 43-51.

IUCN (2011) IUCN Red List of Threatened Species v. 2011.2. Http:// www.iucnredlist.org [accessed 2 February 2012].

Lal, A., Arthur, R., Marbà, N., Lill, A.W.T. \& Alcoverro, T. (2010) Implications of conserving an ecosystem modifier: increasing green turtle (Chelonia mydas) densities substantially alters seagrass meadows. Biological Conservation, 143, 2730-2738.

Nolasco, D., Debade, X. \& Harrison, E. (2007) Report on the 2007 Green Turtle Program at Tortuguero, Costa Rica. Caribbean Conservation Corporation, San Pedro, Costa Rica.

Opay, P. (1998) Hunting green turtles at Tortuguero, Costa Rica. Oryx, $32,10-12$.

Ortiz, R.M., Plotkin, P.T. \& Owens, D.W. (1997) Predation upon olive ridley sea turtles (Lepidochelys olivacea) by the American crocodile (Crocodylus acutus) at Playa Nancite, Costa Rica. Chelonian Conservation and Biology, 2, 585-587.

Polisar, J., Maxit, I., Scognamillo, D., Farrell, L., Sunquist, M. \& EisenberG, J. (2003) Jaguars, pumas, their prey base, and cattle ranching: ecological interpretations of a management problem. Biological Conservation, 109, 297-310.

Pudyatmoko, S., Djumantoko \& Sabarno, Y. (2007) Evidence of banteng (Bos javanicus) decline in Baluran National Park, Indonesia. Journal of Biological Sciences, 7, 854-859.

SAlom-Pérez, R. (2005) Ecologia del jaguar (Panthera onca) y del manigordo (Leopardus pardalis) (Carnivora: Felidae) en el Parque Nacional Corcovado, Costa Rica. MSc thesis, Universidad de Costa Rica, San José, Costa Rica.

Salom-Pérez, R., Carrillo, E., SÁenz, J.C. \& Mora, J.M. (2007) Critical condition of the jaguar Panthera onca population in Corcovado National Park, Costa Rica. Oryx, 41, 51-56.

Sanderson, E.W., Chetkiewicz, C.L.B., Medellin, R.A., Rabinowitz, A., Redford, K.H., Robinson, J.G. \& Taber, A. (2002) Prioridades geográficas para la conservación del jaguar. Fondo de cultura económica, UNAM, Mexico DF, México.

Seminoff, J.A. \& Shanker, K. (2008) Marine turtles and IUCN Red Listing: a review of the process, the pitfalls, and novel assessment approaches. Journal of Experimental Marine Biology and Ecology, 356, 52-68.

Simberloff, D. (1998) Flagships, umbrellas, and keystones: is single-species management passé in the landscape era? Biological Conservation, 83, 247-257.

Smith, R.J., Veríssimo, D. \& MacMillan, D.C. (2011) Marketing and conservation: how to lose friends and influence people. In Trade-Offs in Conservation: Deciding What to Save (eds N. LeaderWilliams, W. Adams \& R. Smith), pp. 215-232. Wiley-Blackwell, Oxford, UK.

Taber, A., Novaro, A., Neris, N. \& Colman, F. (1997) The food habits of sympatric jaguar and puma in the Paraguayan chaco. Biotropica, 29, 204-213.

Troëng, S. (1997) Report on the 1997 Green Turtle Program at Tortuguero, Costa Rica. Caribbean Conservation Corporation, San Pedro, Costa Rica.

Troëng, S. (1999) Report on the 1999 Green Turtle Program at Tortuguero, Costa Rica. Caribbean Conservation Corporation, San Pedro, Costa Rica.

Troëng, S. (2000) Predation of green (Chelonia mydas) and leatherback (Dermochelys coriacea) turtles by jaguars (Panthera onca) at Tortuguero National Park, Costa Rica. Chelonian Conservation and Biology, 3, 751-753. 
Troëng, S., Chacon, D. \& Dick, B. (2004) Possible decline in leatherback turtle Dermochelys coriacea nesting along the coast of Caribbean Central America. Oryx, 38, 395-403.

Troëng, S., Dutton, P.H. \& Evans, D. (2005) Migration of hawksbill turtles Eretmochelys imbricata from Tortuguero, Costa Rica. Ecography, 28, 394-402.

TroËNG, S. \& RanKIN, E. (2005) Long-term conservation efforts contribute to positive green turtle Chelonia mydas nesting trend at Tortuguero, Costa Rica. Biological Conservation, 121, 111-116.

Veríssimo, D., Fraser, I., Groombridge, J., Bristol, R. \& MacMillan, D.C. (2009) Birds as tourism flagship species: a case study of tropical islands. Animal Conservation, 12, 549-558.

Veríssimo, D., MacMillan, D.C. \& Smith, R.J. (2011) Toward a systematic approach for identifying conservation flagships. Conservation Letters, 4, 1-8.

Zeller, K. (2007) Jaguars in the New Millennium Data Set Update: The State of the Jaguar in 2006. Wildlife Conservation Society, New York, USA.

\section{Biographical sketches}

Diogo Verissimo's work at the Durrell Institute of Conservation and Ecology focuses on the adaptation of principles from marketing and economics to improve awareness and fundraising for biodiversity conservation. His research with Global Vision International (GVI) involves the ecology and conservation of marine turtles in the Tortuguero area. David ANEURIN Jones has worked in project management in Europe and Latin America. His interest in edge species and habitats and conservation management stems from work on a range of community and conservation projects, including work with marine turtles, cetaceans, aquatic avifauna, amphibians and large mammals. He worked on the Costa Rica programme of GVI for 3 years. Rebeca Chaverri has developed a GIS-based predictive model of the jaguar and puma in the Osa Wildlife Corridor of Costa Rica. She directed the work of GVI Costa Rica for 3 years. ST tephen R. MEYeR currently manages the Costa Rica programmes of GVI. Previously he managed the GVI programmes in Argentinan Patagonia. 